\title{
СИНКРЕТИЧНИЙ ЕТАП ВЗАЕМОЗВ’ЯЗКУ ФІЛОСОФІЇ ТА МЕДИЦИНИ
}

\author{
Я. М. Попович \\ ДвНЗ «Тернопільський державний медичний університет \\ імені І. Я. Горбачевського МОЗ Украӥни"
}

У статті наведено історичні взаємозв'язки філософії та медицини, а також висвітлено думки видатних філософів та лікарів минулого.

\section{SYNCRETICAL STAGE OF RELATIONSHIPS BETWEEN PHILOSOPHY AND MEDICINE}

\section{Y. M. Popovych}

\section{Horbachevsky Ternopil State Medical University}

The article presents the historical relations of philosophy and medicine, and also highlights the views of prominent philosophers and doctors of the past.

Вступ. Лікування існувало завжди: воно супроводжувало людський побут і свято, виробничу діяльність і релігійні ритуали. Ще до виникнення цивілізованого суспільства людина навчилася лікувати рани і травми, приймати пологи, здійснювати різні маніпуляції з тілом у зв'язку з виконанням обрядів ініціації і т. д. Кесарів розтин, кастрація, трепанація черепа вважаються найдавнішими видами хірургічних операцій, якими людина опанувала вже в далекій давнині.

Виникнення медицини - це новий етап у культурі, який означає, що лікування переходить на більш високий рівень розвитку, набуває характеру свідомо спеціалізованої діяльності. Медицина раціоналізує практику лікування, критично сприймає і разом 3 тим відкидає те, що не витримує критики, не відповідає критеріям тієї науковості, яка виявляється нею засвоєною.

Основна частина. Першим теоретичним фундаментом емпіричного медичного знання виступала філософія або, точніше, «передфілософія» [2]. Даний етап взаємозв'язку філософії із медициною вважають синкретичним. Він передбачав злиття філософського і медичного знання при практичній спрямованості діяльності медика на людину, яка виявлялася в магічному або натурфілософському дусі (тобто, дуже спрощено і без емпіричних підстав). Саме слово

(с) Я. М. Попович, 2017 «синкретика» походить від грецького synkretismos - з'єднання, об'єднання, переплетення [5]. якщо метафізику вважати першим етапом розвитку логіки філософії, діалектику - другим етапом, то синкретика $\epsilon$ третім етапом. Неминучість появи синкретики випливає з того, що абсолютизація однієї або ряду категорій в рамках метафізичної або діалектичної логіки призводить до філософських систем, відірваних одна від одної. В результаті філософія поділяється на окремі напрямки. Синкретика пояснює походження, еволюцію і взаємодію філософських категорій, виявляє їх відносність, що дає можливість незалежно оцінити сутність будь-якої філософської системи і їі місце в філософії. У синкретиці можливо проникнути в основи логіки філософії, у визначення категорії як такої, передбачити можливу повноту законів філософії, їх достатність, необхідність появи нових законів і принципів, вказати способи їх побудови, а в підсумку отримувати нові знання.

Синкретика за своїм змістом формулюється як багатозначна філософська логіка. У синкретиці за основу беруться не окремі категорії, як у метафізиці, не полярно-протилежні категорії, як у діалектиці, а вся сукупність категорій як ціле. Відповідно, зміна сутності предмета мислення повинна змінитися і логіка мислення. За визначенням Вільгельма Фрідріха Оствальда (1853-1932), Х. Дріша і американського 
філософа Райса, «логіка в широкому сенсі є наука про порядок предметів або об'єктів» [6].

Дійсно, якщо є об'єкти і операції над цими об'єктами, то представляючи операції як об'єкти особливого роду, можна уявити мислення як перехід від одного об'єкта до іншого в деякому заданому порядку. Можна також сказати, що логіка впорядковує мислення, і чим більше в ній операцій та об'єктів різного роду, тим логіка складніша, а опис дійсності більш глибокий і точний.

Філософія і медицина однаково давні за походженням феномени культури; їх тісний зв'язок проявляється в близькості предметів дослідження (вивчення людини, її особистості та впливу суспільства на особистість), схожості цілей і завдань, єдності методології, ціннісної орієнтації.

3 моменту підведення під практичне лікування філософського фундаменту виникла колізія розщеплення медицини на теорію і практику, колізія, яка ніколи надалі не зникала, але завжди по-різному інтерпретувалася. Окремо взяте медичне знання це, звичайно, не сам процес лікування хворого або будь-які інші лікувальні дії, наприклад, профілактика захворювань. Медицина як знання безпосередньо лікувати не може, вона виступає лише необхідною умовою, передумовою, основою лікарської дії.

Медицина з моменту свого зародження в давнину головну увагу приділяла тілу людини, організму в цілому, системам і окремим органам, тканинам, клітинам, хімічним процесам, що перебігають в тканинних і рідинних середовищах. Загальна теорія хвороби використовує дані різних наук: анатомії, фізіології, гістології, вірусології, хімії і т. д.

Протягом усієї історії культури ідеї об'єднання філософського і медичного знання заради осягнення таємниці життя і таємниці людини втілювалися в працях найвідоміших філософів, медиків, дослідників природи. У результаті чого склалася особлива галузь знання - філософія медицини, яка покликана узагальнити наявні практичні знання про людину як біологічну і соціальну, матеріальну і духовну істоту та знайти адекватні шляхи адаптації людини до навколишніх умов життя.

У давнину медицина вже виділилася як галузь професійної діяльності, але як система знання вона в той час ще не була науковою теорією. Це не означає, що у лікаря того часу не було знань. Вони, напевно, були, проте, в основному, емпіричні, практичні. Світогляд лікаря був філософським, перевага віддавалася етиці. Внаслідок цього в перший дотеоретичний (синкретичний) період медицини ї̈ етичний, ціннісний зміст виступає на перший план та існує нерозривно з філософськими уявленнями. Саме тому відомий давньоримський лікар Цельс писав: «Спочатку медична наука вважалася частиною філософії...» [7]. До того ж, часто філософ і лікар поєднувалися в одній особі. Чимало відомих філософів були лікарями: Аль-Кінді, ІбнСіна, Ібн-Рушд, Дж. Локк. У середньовічних ісламських університетах в Андалузії курси філософії та медицини були об'єднані під однією назвою - Хікма (мудрість).

У цей період філософія і медицина були єдині, неподільні в теоретичному зв'язку. І якщо природно-наукові уявлення древніх викликають зараз тільки історичний інтерес, то їх етичні погляди цілком актуальні. Подання Епікура про щастя, стоїків про гідність, кініків про свободу не втратили свого значення так само, як i етичні принципи медичної діяльності, сформульовані в Клятві Гіппократа.

Таким чином, перш за все, етична, деонтологічна проблематика об'єднувала філософію і медицину в давнину.

Найдавніші тексти Ассирії та Вавилонії донесли до нас уявлення про джерело хвороб, що цілком відповідали існуючим поглядам на світ. За цими поглядами, $\epsilon$ три основні причини хвороб: «проникнення в тіло злих духів, вплив небесних світил і стан людської крові» [8]. Відповідно, лікування полягало у «вигнанні злих духів», «молитвах богам» і в різноманітних процедурах (масажі, обкурювання травою і загортання у неї, хірургічних операціях). Що ж стосується уявлень про хвороби і здоров'я, то вони ґрунтувалися не на основі медичних, або, ширше, біологічних знань, а на основі існуючого загального світогляду, під впливом якого за допомогою понять, уявлень та ідей будувалася модель хвороби. Першою такою моделлю була магічно-містична модель, що, напевно, виникла разом із міфологічним світоглядом і зафіксована в перших, письмових джерелах, які дійшли до нас, - клинописних написах на глиняних таблицях. До речі, саме в цей час виникає символ медицини - зображення бога медицини Нінгішзідда у вигляді змії, що обвиває жезл і уважно, не кліпаючи, стежить за правильністю дій лікаря. Цей жезл був емблемою, свого роду дипломом, що засвідчує кваліфікацію лікаря, який він завжди мав при собі, відвідуючи хворих.

В античні часи філософія височіла над медициною, оскільки вона, на думку Платона, Арістотеля, Демокріта, Гіппократа, вивчала глибинні сутності життя, 
здоров'я й хвороби як вічні і абсолютні істини. Сама ж медицина може отримати тільки «окреме і відносне знання, істинне тільки в тій мірі, в якій воно відповідає філософії» [4].

У цих натурфілософських рамках формуються перші уявлення про сутність захворювань і здоров'я, наприклад, гуморалізм. Послідовник Емпедокла Гіппократ вважає, що здоров'я і хвороба визначаються правильним (кразією, кресисом) або неправильним (дискразією, дискресисом) поєднанням чотирьох соків (гумором) організму: крові (сангве), слизу (флегма), жовчі (схоле) і чорної жовчі (мелане схоле). Вони відповідають чотирьом першопочаткам Емпедокла (вогню з центром у серці, землі з центром у мозку, повітрю з центром у печінці і воді з центром у селезінці).

У Парацельса вся природа населена злими духами, які розташовуються у хворої людини в шлунку, і для лікування необхідно допомогти верховномужиттєвому духу (цілющій силі).

Як розлад тіла, здатний впливати на його душу, розумів хвороби Фома Аквінський. На синкретичному етапі спекулятивно-філософські моделі захворювань ґрунтуються на натурфілософських уявленнях про дійсність, її устрій і діючі в ній сили. Не було зв'язку з даними спостережень, а істина розумілася схоластично - як відповідність певним уявленням, парадигмі, як ми сказали б тепер.

Прихильниками медичної натурфілософії були не тільки Гіппократ і Арістотель, а й Ібн-Сіна, Ібн-Рушд, Гуфеланд, Вірхов та ін.

Крім того, симбіоз філософських і медичних ідей являє собою давньосхідну мудрість, укладену в єгипетській книзі мертвих, індійських ведах, в навчанні китайських даосів (вчення про безсмертя), а так само в працях лікарів-філософів Сходу (наприклад, Авіценна) [3].

Основою східної філософії медицини завжди залишався принцип системності у вивченні мікро- і макрокосму, особливістю - розгляд людського організму як самодостатньої сутності, в якій нерозривно пов'язані дух і тіло; хвороби тіла тут розглядаються насамперед як хвороби духу, відповідно, лікування хвороби - це насамперед відновлення душевної рівноваги і духовного здоров'я.
У Стародавній Греції - колисці філософського знання - філософія і медицина так само тісно співпрацюють і взаємозбагачуються. Їх об'єднує прагнення розібратися в людській психіці, спроба відповісти на питання: що є людина; яка (особиста і суспільна) цінність людського здоров'я; чи є людина істотою біологічною або соціальною (ці питання розглядаються в роботах таких знаменитих старогрецьких лікарів і філософів, як Емпедокл, Арістотель, Гіппократ та ін.).

У середньовічній європейській традиції філософські та медичні дослідження продовжуються паралельно. Активно розвивається нова галузь знання, що знаходиться на стику філософії, медицини і природничонаукових досліджень (насамперед хімії), що включає так само елементи ворожби і чаклунства, - алхімія. Незважаючи на нереальні цілі (пошуки еліксиру життя або філософського каменю), алхімія відіграла позитивну роль як у вивченні людської істоти (Дж. Фракасто), так і в розробці деяких прийомів лабораторної техніки, особливо необхідної для розвитку практичної медицини (наприклад, перегонка, сублімація та ін.). Європейські лікарі-філософи епохи Середньовіччя (Ф. Рабле, Р. Бекон, Парацельс й ін.) передбачили багато наступних медичних відкриттів і розробок, прийоми лікування хвороб; вони так само вивчали вплив суспільства (соціального статусу особистості) на розвиток патологічних процесів в організмі. Долаючи і переглядаючи багато основ стародавньої медицини і філософії людини, середньовічні вчені, натуралісти сприяли впровадженню хімічних препаратів у медицину, а так само заклали основи теорії адаптації людини в навколишньому середовищі.

Висновки. Незважаючи на різні напрямки діяльності та різні шляхи пошуку істини (медицина вибирає на зорі свого існування шлях практичної дії, філософія шлях теоретичного узагальнення і рефлексії), обидві вони вирішують одну і ту ж проблему - проблему виживання людства на Землі, проблему самовизначення людини як природної і культурної істоти. У цьому питанні філософія і медицина не можуть не об'єднати свої зусилля, оскільки порізно вони позбавлені цілісності - філософія віддаляється від емпірії, «витає в хмарах», медицина ж, занурюючись в дослідження організму, забуває про особу, «потопає» у деталях і подробицях [1]. 


\section{СПИСОК ЛІТЕРАТУРИ}

1. Бережной Н. М. К проблеме комплексного изучения человека / Н. М. Бережной // Философские науки. - 1991. № 1. - С. 17-19.

2. Философия медицины - самосознание терапии. Вызовы времени и современная российская медицина / сб. статей и тезисов докладов. - Екатеринбург : УгМУ. 2014. - Т. 1. - 243 c.

3. Шульга Е. Н. Здоровье в контексте философскоисторического анализа / Е. Н. Шульга // Здоровье как проблема естественных и биомедицинских наук / И. К. Лисеев, Е. Н. Гнатик. - М. : ИФ РАН, 2008. - 292 с.

4. Шевченко Ю. Л. Философия медицины / под ред. Ю. Л. Шевченко. - М. : ГЭОТАР-Медиа, 2004. - 480 с.
5. Философия : учебник / под ред. В. Д. Губина, Т. Ю. Сидориной, В. П. Филатова. - М., 2008. - 345 с.

6. Хрусталев Ю. М. Философские проблемы медицины / Ю. М. Хрусталев, Г.И.Царегородцев // Философия естественных наук; под ред. С. А. Лебедева. - М., 2006. С. 475-550.

7. Философия медицины / под ред. Ю. Л. Шевченко. М., 2004. - 480 c.

8. Хрусталев Ю. М. Философия науки и медицины / Ю. М. Хрусталев, Г. И. Царегородцев. - М. : ГЭОТАР-Медиа, 2007. - 512 c.

Отримано 30.10.17 